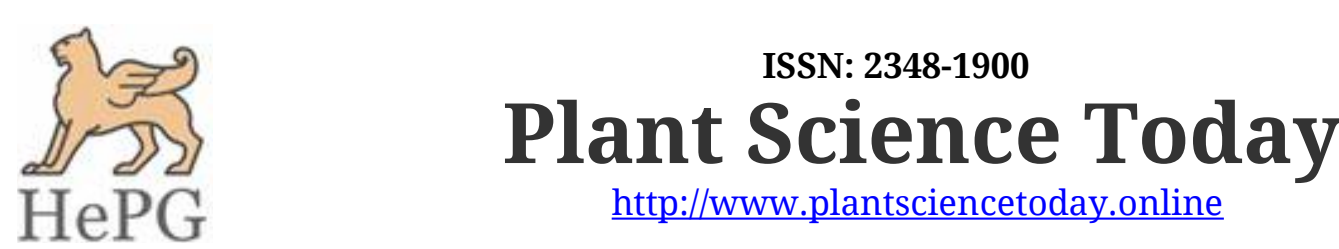

OPEN (-) ACCESS

Research Article

\title{
Morphological variations in geographically isolated populations of Bryum coronatum Schwager (Bryaceae, Bryales)
}

\author{
Shewli Bhattacharya ${ }^{1}$, Sri Narayan 0jha ${ }^{2^{*}} \&$ Samit Ray $^{1}$ \\ ${ }^{1}$ Department of Botany, Visva Bharati, Santiniketan, West Bengal, India \\ ${ }^{2}$ Integrated Science Education and Research Centre, Visva Bharati, Santiniketan, West Bengal, India
}

\section{Article history}

Received: 01 April 2019

Accepted: 17 June 2019

Published: 01 September 2019

\section{Publisher}

Horizon e-Publishing Group

\footnotetext{
*Correspondence

Sri Narayan Ojha

凶snojha2@gmail.com
}

\begin{abstract}
Four populations of Bryum coronatum Schwager (Bryaceae, Bryales), collected from widely separated geographic regions - Sambalpur, Odisha; Lataguri, West Bengal; Gangtok and Changu, Sikkim; were studied with regard to variation in taxonomically significant morphological features as well as their dimension of both gametophytic and sporophytic features. In this study special emphasis has been put on spore dimension and spore ornamentation pattern as revealed by Scanning Electron Microscopy (SEM). Dimension of taxonomically significant morphological parameters were measured for four populations and were subjected to analysis of variance (One way ANOVA) and Principal component analysis (PCA). ANNOVA results showed significant variation for all features except leaf length and upper leaf cell breadth. PCA results corroborated ANNOVA result only for upper leaf cell breadth. Spore ornamentation as revealed through SEM, is found to be bacculate in all the populations. CCA graph revealed that summer, winter temperature and monsoon rainfall influence leaf size, lamina cell size, capsule size, peristome size and spore size. With the help of above mentioned observations and statistical analysis the morphological variations, due to phenotypic plasticity have been quantified to reach at a meaningful conclusion. Taxonomic significance of spore dimension and wall ornamentation is also discussed.
\end{abstract}

Keywords: ANOVA; Bryum coronatum; morphological variations; moss, Principal Component Analysis; Canonical Correspondence Analysis

Citation: Bhattacharya S, Ojha SN, Ray S. Morphological variations in geographically isolated populations of Bryum coronatum Schwager (Bryaceae, Bryales). Plant Science Today 2019; 6(3):360-366. https://doi.org/10.14719/pst.2019.6.3.543

\begin{abstract}
Copyright: (c) Bhattacharya et al (2019). This is an open-access article distributed under the terms of the Creative Commons Attribution License, which permits unrestricted use, distribution, and reproduction in any medium, provided the original author and source are credited (https://creativecommons.org/licenses/by/4.0/).
\end{abstract}

Indexing: Plant Science Today is covered by Scopus,Web of Science, BIOSIS Previews, ESCI, CAS, AGRIS, CABI, Google Scholar, etc. Full list at http://www.plantsciencetoday.online

\section{Introduction}

The genus Bryum Hedw. is placed in the family Bryaceae, order Bryales (1). This genus is widely distributed in tropical and subtropical regions of India $(2,3)$. The genus shows high morphological plasticity and thus represented by 700 species (2). It is represented in India by a large number of species 
that inhabit all climatic zones from the plains to the higher altitudes of the Himalayas $(2,4,5)$. Gangulee (2) identified the species of Bryum on the basis of length of plant, size of leaf, size of lamina cells, size of capsule urn (the portion from mouth of the capsule to the point of attachment of seta), peristome type and height and spore diameter. However, these parameters are expected to show variations depending upon the geographical regions in which they are occurring and this creates problem in ascertaining the identity of a species. This variability is described as phenotypic plasticity. In response to environmental conditions phenotypic plasticity helps individuals to alter traits. It is expected to be an important way for organisms to deal with variable environments (6). Such kinds of variation of taxonomically important features have been reported in mosses like Pogonatun dentum, Calliergonella cuspidata (7, 8). Shaw (9) studied morphological characters of both gametophytic and sporophytic generations of geographically disjunctive 76 populations of Scopelophila cataractae to assess whether subtle differences exist between plants from widely separated populations. It was clearly shown by statistical analyses that morphological features of plants from widely disjunct populations confirm the existence of significant variation among populations. Bryum coronatum, a commonly occurring species of Bryum, is found in different phytogeographical regions of India - Sikkim, Manipur, Darjeeling, Rajasthan, Calcutta, Howrah, Orissa (Cuttack, Puri, Koraput), Western Ghats, Maramalmalai, Kanyakumari district, Tirunelveli district, Mundanthurai (10). The present work has been undertaken with the following objectives - (i) to study morphological variations of four different populations of $B$. coronatum (collected from four different widely separated places) with regard to gametophytic and sporophytic features including spore diameter, polar axis length, equatorial diameter and SEM study of spore ornamentation; (ii) to find out correlation between climatic parameters and morphological variations.

Note: SEM study of ornamentation of external wall of spore, measuring spore dimension with regard to polar axis and equatorial diameter, quantification of dimensional variation of various features by statistical method and correlating morphological variation with environmental factors are being studied for the first time with regard to Indian species of mosses.

\section{Materials and Methods}

Locations of collected populations: Four populations of Bryum coronatum were collected from the following four locations - Sambalpur, Odisha $-21.4700^{\circ} \mathrm{N}, 83.9700^{\circ} \mathrm{E}$; Lataguri, West Bengal $-26.7063^{\circ} \mathrm{N}, 88.7661^{\circ} \mathrm{E}$; Gangtok, Sikkim $27.3300^{\circ} \mathrm{N}, \quad 88.6200^{\circ} \mathrm{E} ; \quad$ Changu, Sikkim $27.3745576^{\circ} \mathrm{N}, 88.7632283^{\circ} \mathrm{E}$.
Methods of collection, preservation and study: Populations of $B$. coronatum were collected from the field and brought to the laboratory in plastic packets. The plants were studied under dissecting microscope (Hund, Wetzlar). Photographs of the gametophores and other taxonomically significant features were taken using trinocular microscope (Leica DM 2500). Taxonomic identification was carried out following (11). Collected specimens were preserved in the herbarium of CSIR-National Botanical Research Institute, Lucknow (AcronymLWG) No. VB / LWG No.1.

Collection of morphometric and climatic data: Gametophytic characters like - stem length, leaf length and breadth, upper leaf cell length and breadth, lower leaf cell length and breadth and four sporophytic characters - seta length, capsule urn length and breadth and peristome teeth height were measured. Characters related to spores (acetolysed) studied are - spore diameters, polar axis and equatorial axis. In case of study of dimension, ten plants of each population were studied and were subjected to statistical analysis. Climatic data of each of four locations, used in statistical analysis, were collected from meteorological office.

Acetolysis: Acetolysis of spores of four populations of $B$. coronatum was done following the method of Erdtman (12). Acetolysed spores were used for measurement of dimension (spore diameter, polar axis, equatorial axis). Dimensions related to spore were recorded under trinocular microscope with the help of related software.

Scanning electron microscopy: Non-acetolysed dry spores were dusted from the capsule on the stub with double sided sticky tape for SEM. The spores were coated with Gold-Paladium by a sputter coater and observed with Hitachi S530 SEM at an accelerated voltage of $15 \mathrm{KV}$ (located at sophisticated instrumentation center of Burdwan University).

Statistical analysis: The morphometric data of eleven gametophytic features (including spore dimension) and four sporophytic morphological parameters were subjected to analysis of variance (One way - ANOVA). Values for each morphological trait in all populations were an average of ten plants per population. Morphometric data and spore dimension were subjected to Principal component analysis (PCA) based ordination by combining all the data and also by taking data for each parameter separately. The calculation was carried out using open source $\mathrm{R}$ software package. Canonical Correspondence Analysis (CCA) (13) was performed to determine whether variance in the morphological dimensions could be explained by climatic variables of three locations from which the populations were collected. CCA ordination was tested for significance with a Monte Carlo test (500 runs) through CANOCO software. 
Table 1. Range of values of morphometric parameters studied

\begin{tabular}{lrrrrr}
\hline \multicolumn{1}{c}{ Morphological parameter (mm) } & $\begin{array}{c}\text { B. coronatum } \\
\text { from } \\
\text { Sambalpur }\end{array}$ & $\begin{array}{c}\text { B. coronatum } \\
\text { from } \\
\text { Lataguri }\end{array}$ & $\begin{array}{c}\text { B. coronatum } \\
\text { from } \\
\text { Gangtok }\end{array}$ & $\begin{array}{c}\text { B. coronatum } \\
\text { from } \\
\text { Changu }\end{array}$ \\
\hline Stem length & $7.0 \sim 11.0$ & $9.0 \sim 14.0$ & $8.0 \sim 15.0$ & $5.0 \sim 13.0$ \\
\hline Leaf length & $1.9 \sim 2.5$ & $2.03 \sim 2.8$ & $1.5 \sim 2.8$ & $1.5 \sim 3$ \\
\hline Leaf breadth & $0.542 \sim 0.633$ & $0.31 \sim 0.45$ & $0.3 \sim 0.55$ & $0.32 \sim 0.45$ \\
\hline Upper leaf cell length & $0.053 \sim 0.06$ & $0.053 \sim 0.062$ & $0.059 \sim 0.08$ & $0.08 \sim 0.084$ \\
\hline Upper leaf cell breadth & $0.006 \sim 0.0085$ & $0.0032 \sim 0.0059$ & $0.008 \sim 0.011$ & $0.008 \sim 0.0085$ \\
\hline Lower leaf cell length & $0.03 \sim 0.042$ & $0.044 \sim 0.052$ & $0.038 \sim 0.066$ & $0.047 \sim 0.064$ \\
\hline Lower leaf cell breadth & $0.0092 \sim 0.013$ & $0.01 \sim 0.014$ & $0.012 \sim 0.015$ & $0.01 \sim 0.016$ \\
\hline Seta length & $13.0 \sim 20.0$ & $14.0 \sim 20.0$ & $16.0 \sim 24.0$ & $23.0 \sim 24.5$ \\
\hline Capsule urn length & $1.7 \sim 2.1$ & $1.0 \sim 1.48$ & $1.8 \sim 2.0$ & $1.7 \sim 2.1$ \\
\hline Capsule urn breadth & $0.8 \sim 1.1$ & $0.77 \sim 0.94$ & $0.8 \sim 1.0$ & $1.0 \sim 2.1$ \\
\hline Peristome height & $0.43 \sim 0.49$ & $0.22 \sim 0.47$ & $0.47 \sim 0.63$ & $0.53 \sim 0.57$ \\
\hline Polar axis of spore & $0.0068 \sim 0.010$ & $0.0066 \sim 0.0095$ & $0.0081 \sim 0.0100$ & $0.0067 \sim 0.008$ \\
\hline Equatorial diameter of spore & $0.0088 \sim 0.011$ & $0.0076 \sim 0.0107$ & $0.0087 \sim 0.0115$ & $0.0086 \sim 0.0099$ \\
\hline Ornamentation & Baculate & Baculate & Baculate & Baculate \\
\hline
\end{tabular}
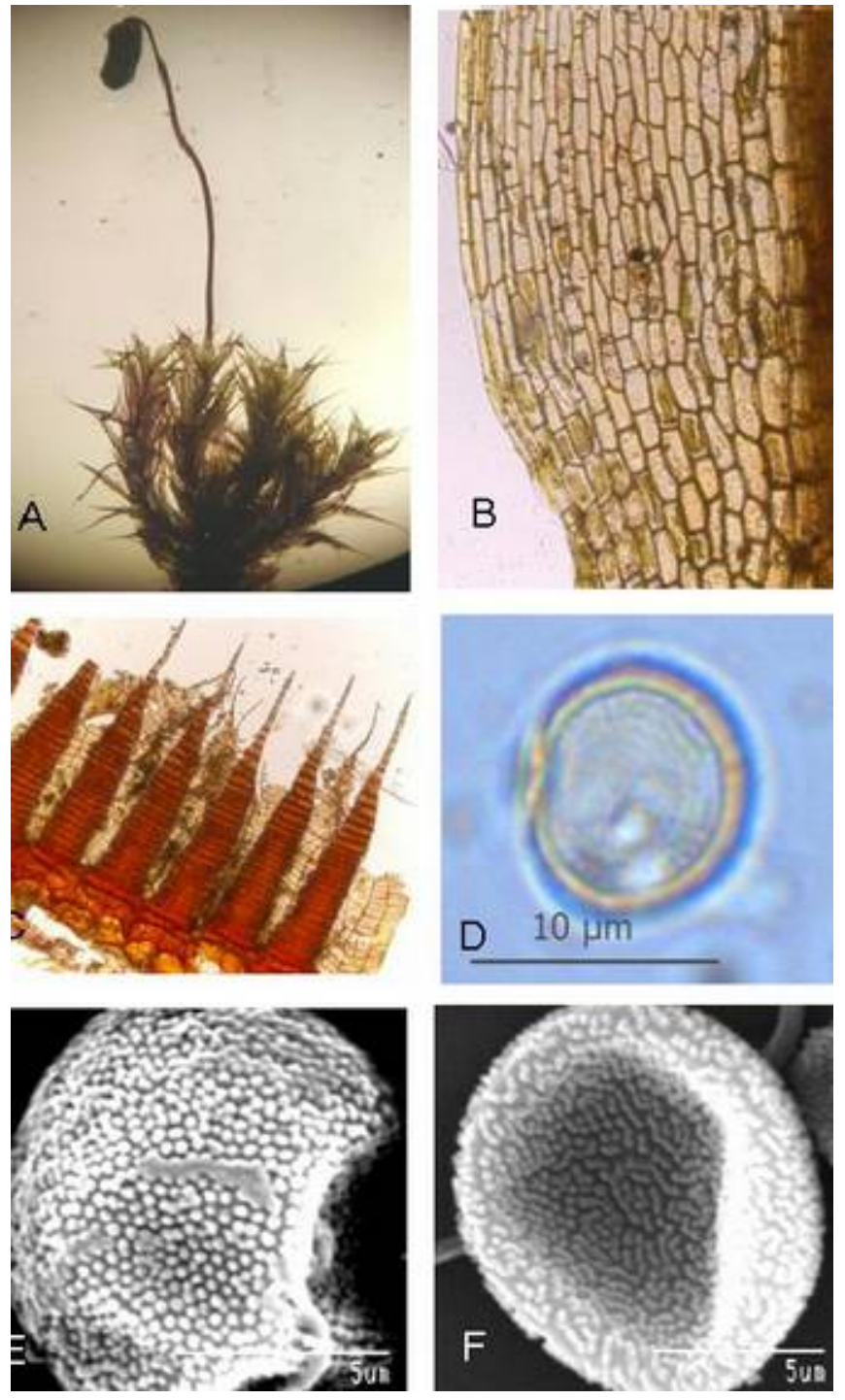

Plate 1. Plate showing (A) habit, (B) alar cells, (C) peristome teeth, (D) spore, (E \& F) SEM photographs of spores of $B$. coronatum

\section{Results}

\section{Specimens examined}

Population I: India, Sikkim, Gangtok, $27.3300^{\circ} \mathrm{N}$, $88.6200^{\circ}$ E, 2.2.2011, Samit Ray, SK 33, Terrestrial.

Population II: India, Sikkim, Changu, $27.3745576^{\circ} \mathrm{N}, 88,7632283^{\circ} \mathrm{E}, 2.4 .2011$, Samit Ray, SK 37, Terrestrial.

Population III: India, West Bengal, Jalpaiguri, Lataguri, $26.7063^{\circ} \mathrm{N}, 88.7661^{\circ} \mathrm{E}, 10.20 .2013$, Samit Ray, WB 62, on brick and cement wall.

Population IV: India, Orissa, Sambalpur $21.4700^{\circ} \mathrm{N}$, $83.9700^{\circ} \mathrm{E}, 4.14 .2012$, Samit Ray, OR 4, on brick wall.

\section{Description of $B$. coronatum Schwaegr}

Plants dull green, densely tufted, tomentose at base; stem branched from base; lower leaves smaller, upper leaves ovate to oblong lanceolate, contorted when dry, margin entire, flat, costa strong, excurrent; upper leaf cells narrow rhomboid to hexagonal; basal cells shorter rectangular, thin-walled; capsule pendulous, thick, shaped like a cup in another cup; seta apical, erect, but arcuate at tip, red to purple; spongy apophysis shorter than capsule and provided with stomata; operculum big, conical; outer peristome reddish, teeth broad lanceolate with sharp, hyaline, papillose tips; endostome transparent yellow, finely papillose, as high as exostome, with 2 to 3 appendiculate cilia; spores 7.6 to $11.5 \mu$ in diameter (Plate 1).

\section{Morphometric parameters}

Table 1 shows the wide range of differences among dimensional morphometric parameters of four populations. 
Table 2. Environmental data of four locations

\begin{tabular}{lccrrrrr}
\hline Location & $\begin{array}{c}\text { Summer } \\
\text { Temp. } \\
\left({ }^{\circ} \mathbf{C}\right)\end{array}$ & $\begin{array}{c}\text { Winter } \\
\text { Temp. } \\
\left({ }^{\circ} \mathbf{C}\right)\end{array}$ & $\begin{array}{c}\text { Elevation } \\
(\mathbf{m})\end{array}$ & $\begin{array}{c}\text { Winter rainfall } \\
(\mathbf{m m})\end{array}$ & $\begin{array}{c}\text { Summer } \\
\text { rainfall } \\
(\mathbf{m m})\end{array}$ & $\begin{array}{c}\text { Monsoon } \\
\text { rainfall } \\
(\mathbf{m m})\end{array}$ \\
\hline Gangtok & 20.16 & 04.8 & 1600 & 44.23 & 319.26 & 608.9 \\
\hline Changu & 22.60 & 09.9 & 1421 & 09.00 & 15.66 & 70.00 & 19.26 \\
\hline Sambalpur & 38.50 & 28.3 & 134 & 49.16 & 38.83 & 388.46 \\
\hline Lataguri & 27.50 & 14.0 & 99 & 41.03 \\
\hline
\end{tabular}

Table 3. ANOVA result

\begin{tabular}{lr}
\hline \multicolumn{1}{c}{ Morphological parameter (mm) } & Level of significance (p) \\
\hline Stem length & Not significant \\
\hline Leaf length & E-10 \\
\hline Leaf breadth & E-15 \\
\hline Upper leaf cell length & Not significant \\
\hline Upper leaf cell breadth & E-06 \\
\hline Lower leaf cell length & 0.001845 \\
\hline Lower leaf cell breadth & E-07 \\
\hline Seta length & E-08 \\
\hline Capsule urn length & E-10 \\
\hline Capsule urn breadth & E-09 \\
\hline Peristome height & E-06 \\
\hline Spore diameter & 0.018417 \\
\hline Polar axis of spore & 0.002755 \\
\hline Equatorial diameter of spore & \\
\hline
\end{tabular}

*E-X denotes $10^{-\mathrm{X}}$

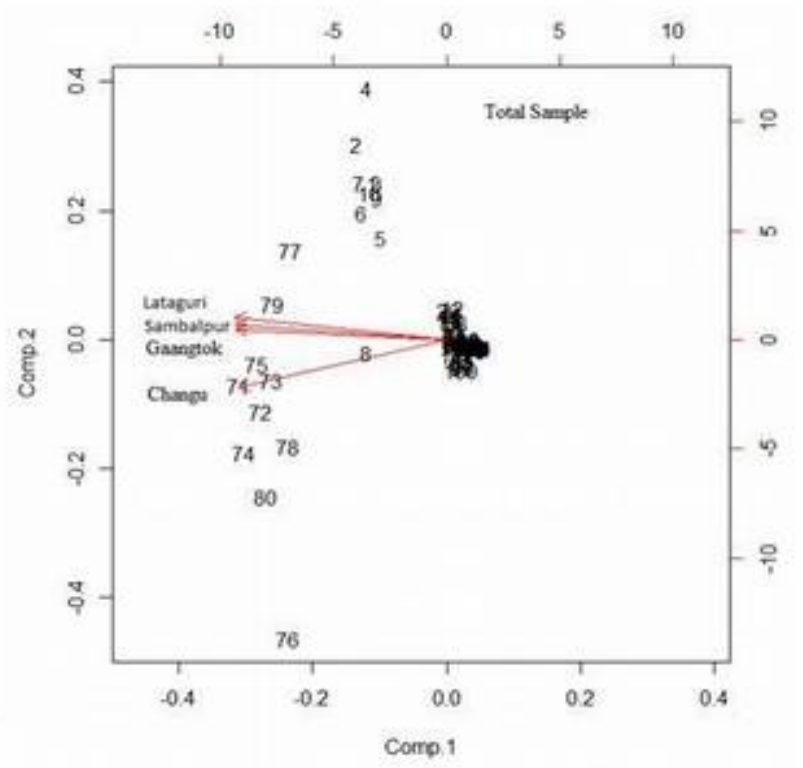

Fig. 1. PCA graphs based on composite data of all parameters of four populations

\section{Spore dimension}

Polar axis and equatorial diameter of spores of population collected from Gangtok are 8.1 10 $\mu \mathrm{m}$ and 8.7 11.5 $\mu \mathrm{m}$ respectively. Whereas polar axis and equatorial diameter of spores of population collected from Lataguri are $6.6 \sim 9.5 \mu \mathrm{m}$ and $8.1 \sim 10 \mu \mathrm{m}$ respectively. Spore size of population from Gangtok is the largest and spore size of population from Lataguri is the smallest among four sites.

\section{Spore wall ornamentation}

SEM revealed that spore ornamentation of each population of B. coronatum is baculate (Plate 1 ).

\section{Environmental Data of four locations}

Environmental data (Table 2) shows that Sambalpur has highest summer and winter temp. Gangtok is the highest elevated spot. Summer and winter rainfall are in high amount at Gangtok.

\section{ANOVA results}

The four populations of $B$. coronatum showed uniformity in taxonomically significant morphological features. The values of morphometric parameters are given in Table 1 . ANOVA conducted with dimensions of the samples from four locations show highly significant differences in the dimensions of morphological 


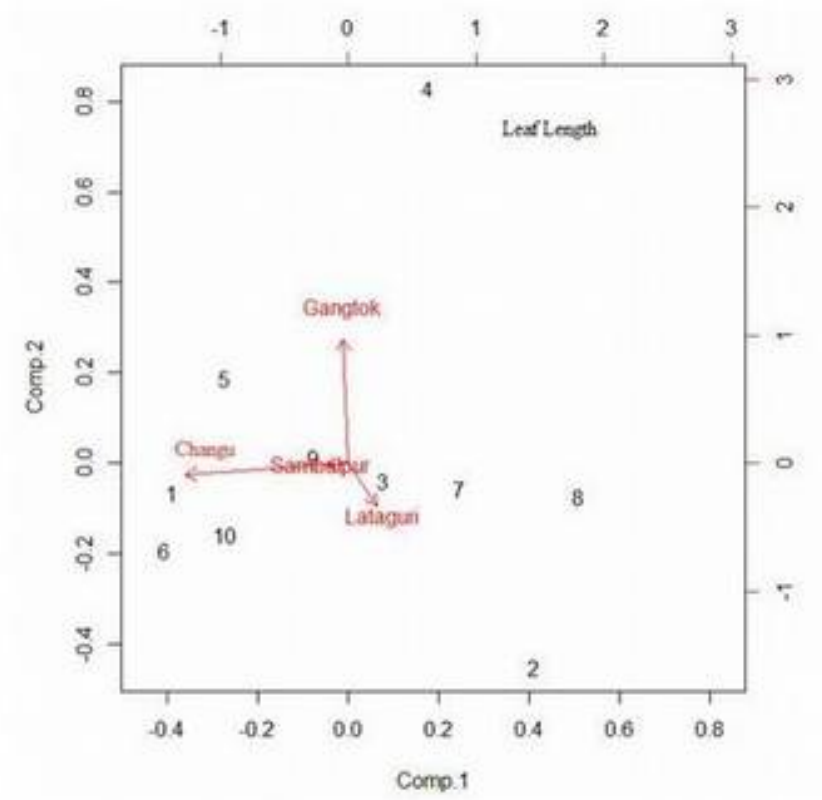

Fig. 2. PCA graphs based on leaf length of four populations

parameters (Table 3). The ANOVA result was found not significant for measured differences in leaf length and upper leaf cell breadth.

\section{PCA results}

PCA analysis with regard to leaf length does not support the ANOVA result as there is segregation of sample points in three clusters (Fig. 1). But it corroborates the ANOVA result regarding the parameter of upper leaf cell breadth as this parameter does not differentiate the sampling locations on orthogonal (perpendicular distinction) basis. PCA result of composite data related to studied features for four sampling locations shows all the four locations to be distinguished while the difference of Changu is more pronounced (Fig. 2).

\section{CCA results}

Table 2 shows the environmental data of four locations. Among these four, Changu has highest elevation and very low temperature during winter. In Gangtok, there is heavy rainfall during summer and monsoon. The 13 morphometric variables $(\Delta)$ and the 5 environmental variables (directional line) are depicted in the CCA ordination space to elucidate the mutual relationship. The relative weight, as denoted by extra-fit values, for the variables indicates a wide variation (0.0007 to 0.0097$)$ with a p-value of 0.05 . The eigenvalues for corresponding axes indicate that first two axes are equally contributing in explaining the species-environment relationship. Axis 1 has negative correlation with summer temperature, winter temperature and winter rainfall and Axis 2 has negative correlation with elevation, winter rainfall and summer rainfall. As the axes are canonical, the plot of species on the

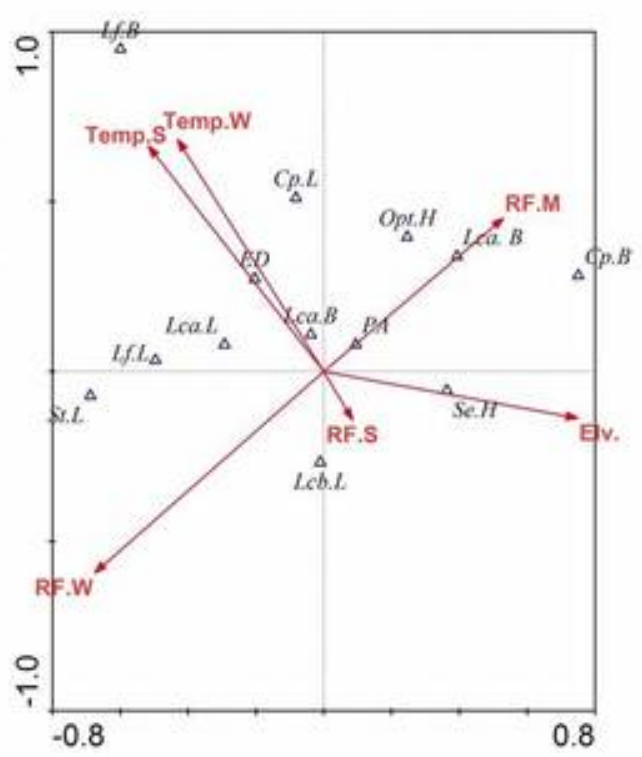

Fig. 3. CCA graphs showing correlation between morphometric parameters and environmental variables

diagram can be easily interpreted in terms of the environmental gradient. CCA graph (Fig. 3) shows that leaf size ( $L f . L \& L f . B$ ), lamina cell size ( $L c a . L$, $L c a . B, L c b . B)$, capsule size (Cp.L), peristome height $(O p t . H)$ \& Spore size $(P A, E D)$ are influenced by monsoon rainfall (RF.M), Winter temperature (Temp.W) \& Summer temperature (Temp.S). Seta height $(\mathrm{Se} . \mathrm{H})$ is dependent upon elevation (Elv.) Summer rain fall (RF.S) influences basal cell length of lamina $(L c b . L)$.

\section{Discussion}

Among the biogeographical regions of India, Eastern Himalayan range is considered as one of the centres of origin and diversification of the bryophytes (14). Gangulee (2) reported occurrence of Bryum coronatum from Sikkim, various parts of West Bengal including Darjeeling hills and gangetic plains as well as Orissa (Cuttak, Puri, Koraput). This species might have spread gradually in different phytogeographical regions of India. A new population of this species is reported here from Sambalpur, Orissa.

Table1 clearly shows that there are morphological and morphpmetric (dimension of various morphological features) variations between populations of $B$. coronatum collected from widely separated geographical locations. This indicates origin of variability, particularly with regard to dimensions, as different populations get widely spread.

In addition to other morphological features ornamentation of spore wall external layers revealed through SEM and spore equatorial diameter have been considered taxonomically significant features for moss identification (15-18). 
Spore diameter of a population of $B$. coronatum is $8.3-10.2 \mu \mathrm{m}$ (19). In some Indian populations of B. coronatum spore dimension reported is $8-9 \mu \mathrm{m}$ (3). In the present study, the range of spore diameter measured is $7.6-11.5 \mu \mathrm{m}$ and it varied among populations studied. In a study it was revealed that spore size is larger in populations from higher altitude. There were also reports on greater spore diameter in Funaria population from Darjeeling as compared to populations from plains (21). Variation of spore dimention in the taxa collected in the present study has been discussed in this context. In the present study the spore dimention has been measured with regard to polar axis and equatorial diameter. Among the collection sites Gangtok is located at higher altitude and spores from this population have largest polar axis (8.1-10.0 $\mu \mathrm{m})$ and equatorial diameter (8.7-11.5 $\mu \mathrm{m})$. Population from lowest altitude (Lataguri) has smallest dimension.

Above data clearly indicates that there is apparently not much variation in spore diameter in various populations collected from widely separated geographical regions. Ornamentation pattern reported in $B$. coronatum is regularly arranged sparse short bacculate type (19). In another study on nine species of Bryum, collected from both Western and Easterm Himalayas. Of these, six species were found to have bacculate spore ornamentation while other three species of Bryum studied showed papillate ornamentation (3). Intra-specific variation is quite evident from this study. Similar bacculate type ornamentation is found in all the populations studied in the present investigation. It is evident from the above discussion that two parameters, related to spore, emphasized upon show variations as well as similarity between different populations of the same species. So, it can be inferred that spore wall ornamentation and spore dimension should be studied with other morphological features for proper taxonomic identification.

In present study, ANOVA was used to show significant differences in dimensional aspect of twelve phenotypic characters (important for taxonomic identification of species) of four populations of $B$. coronatum. The outcome of ANOVA test establishes that widely separated populations show significant variation (Table 3 ) in morphometric data with regard to most of the taxonomically significant features. But the ANOVA result does not provide individual distinction between any two sampling locations. As we have more than two sampling locations, ANOVA cannot tell us as to which specific pair of locations is mutually different. Further, the proximity of sampling location may also be reflected in the morphometric data for which PCA provides a more reliable analytical method. PCA result corroborates ANOVA result only for the parameter of leaf cell breadth. It provides an explanation for leaf length in terms of mutual similarity and dissimilarity across the four sampling locations. In PCA graph of composite data regarding all studied parameters, the remarkable segregation of the population from Changu may be due to the altitude and environment. But considering the close association of population of Sambalpur and Gangtok in the Fig. 1 which are otherwise geographically widely separated, it can be concluded that ecological factors are not the sole reason for morphological distinctions across the fourteen parameters among the four populations. Phenotypic plasticity can act as a contributor to morphological variability. But spore ornamentation of these four populations of $B$. coronatum remains unchanged and indicates its conservative nature (Table 1). CCA analysis performed showed that altitude, vegetation coverage and temperature were the key factors influencing the distribution of a moss Didymodon (22). An earlier study on various populations of Funaria through CCA analysis shows that, elevation and winter rain fall are the most influencing factors regarding the variations found in leaf, capsule, peristome teeth and spore size of three different populations of Funaria (21). In the present work, summer and winter temperature and monsoon rainfall influence leaf size, lamina cell size, capsule size, peristome size and spore size (Fig. 3). Environment is an inducing factor for phenotypic plasticity (23). These observations support earlier observation that phenotypic expression of various features particularly with regard to to dimension is dependent on environmental factors (23). Consistency of these features in various locations must be considered before they are used for the purpose of taxonomy.

It is thus concluded that - (i) geographically distant populations of $B$. coronatum show significant differences in dimensions of certain morphological parameters. However, this variation can not always be correlated with ecological parameters, (ii) in some cases there is distinct correlation between changing climatic factors and the morphometric parameters. So, dimensions of different parts of gametophore and sporophyte should not be used for every morphological feature used to prepare the key of species identification. However, more populations from other localities should be studied in this regard, (iii) bacculate spore wall ornamentation pattern is found to be the dominant feature in various populations of $B$. coronatum. Considering the fact that there are interspecific variations both in spore ornamentation and dimensional aspects, it is inferred that features related to spores must be considered in addition to other morphological features as identification parameters for species.

\section{Acknowledgements}

The authors gratefully acknowledge the research facilities provided by the Department of Botany, Visva Bharati. 


\section{Authors' contributions}

SB has done the morphological and morphometric studies and Canonical correspondence analysis. SNO has contributed by doing all statistical analyses and manuscript preparation, SR has done the overall planning, collection of populations, SEM study and writing the manuscript.

\section{Competing Interests}

The authors declared that they have no conflict of interest.

\section{References}

1. Goffinet B, Buck WR, Shaw AJ. Morphology, Anatomy and Classification of the Bryophyta. In: Goffinet A. Shaw J, editors. Bryophyte Biology. Cambridge University Press; 2009. p. 55 - 138.

2. Gangulee HC. Mosses of Eastern India and adjacent regions, Fascicle I.1969, Fascicle II.1971, Fascicle III.1972, Fascicle IV.1974, Fascicle V.1975, Fascicle VI.1977, Fascicle VII.1978, Fascicle VIII.1980. Eastend printers: Kolkata, India; $1974-80$.

3. Bansal P, Nath V. Current status of genus Bryum Hedw. in Eastern Himalaya, India. Taiwania 2013; 58 (3): 205-12.

4. Lal J. A check list of Indian mosses. Bishen Singh and Mahendra Pal Singh: Dehradun, India; 2005.

5. Dandotiya D, Govindapyari H, Suman S, Uniyal P.L. Checklist of the bryophytes of India. Archive for bryology 2011; 88: 1-126.

6. Schlichting CD. The evolution of phenotypic plasticity in plants. Annu Rev Ecol Systemat. 1986; 17: 667-93. https://doi.org/10.1146/annurev.es.17.110186.003315

7. Bergami A, Peintinger M. Effects of light and nitrogen on morphological plasticity of the moss Calliergonella cuspidata. Oikos 2002; 96: 355-63. https://doi.org/10.1034/j.1600-0706.2002.960217.x

8. Hassel K, Pedersen B, Söderström L. Changes in lifehistory traits in an expanding moss species: phenotypic plasticity or genetic differentiation? A reciprocal transplantation experiment with Poganatum dentatum. Ecography 2005; 28: 71 - 80. https://doi.org/10.1111/j.0906-7590.2005.03910.x

9. Shaw AJ. Morphological uniformity among widely disjunct populations of the rare "Copper moss" Scopelophila cataractae (Pottiaceae). Systematic Botany 1993; 18(3): 525-37. https://doi.org/10.2307/2419424
10. Bansal P, Nath V. A new record of Bryum coronatum Schwaer. (Bryophyte) in Meghalaya, India. Taiwania 2012; 57 (3): 294-99.

11. Gangulee HC. Mosses of Eastern India and adjacent regions, Vol. II (Fasc. 4 - 6). Books and Allied Limited, Kolkata, India; 1969-77.

12. Erdtman G. The acetolysis method. Svensk botanisk tidskrift 1960; 54: 561-64.

13. Ter Braak CJF. Canonical correspondence analysis: A new eigen vector technique for multivariate direct gradient analysis. Ecology 1986; 67: 1167-79. https://doi.org/10.2307/1938672

14. Dixon HN. Mosses collected in Assam. Journal of Bombay Natural History Society 1937; 39: 769-95.

15. Luzi-ponzo AP, Barth OM. Spore morphology of some Bruchiaceae species (Bryophyta) from Brazil. Grana 1998; $\quad 37 \quad$ (4): $\quad 222-27$ https://doi.org/10.1080/00173139809362670

16. Luzi-ponzo AP, Barth OM. Spore morphology of some Dicranaceae species (Bryophyta) from Brazil. Grana 1999; 38:42-49.

17. Savaroğlu F, Erkara IP. Baycu C. Alkan M. Spore morphology of some Bryaceae Schwigr. species (Bryophyta) from Turkey. International Journal of Nature and Engnieering Sciences 2007; 1 (2): 49 - 54.

18. Savaroğlu F, Erkario P. Observation of spore morphology of some Pottiaceae Schimp. species (Bryophyta) in Turkey. Plant Systematics and Evolution 2008; 271: 93-99. https://doi.org/10.1007/s00606-007-0607-1

19. Gui-Sen D, Mei-Zhi W, Yu-Long Z. A study on the spore morphology of Bryum Hedw. China. Acta Phytotaxonomica Sinica 1998; 36 (5): 436 - 440.

20. Robinson H. Notes on Bryophytes from the Himalayas and Assam. Bryologist 1968; 71: 82-97. https://doi.org/ 10.1639/0007-2745(1968)71[82:NOBFTH]2.0.CO:2

21. Bhattacharya S, Ojha SN, Ray S. Variation in gametophytic and sporophytic features among three disjunct populations of Funaria hygrometrica. Nelumbo 2017; 59 (1): 110-17. https://doi.org/10.20324/ nelumbo/v59/2017/117146

22. Song S, Liu X, Bai X, Jiang Y, Zang X, Yu C, Shao X. Impacts of environmental heterogeneity on moss diversity and distribution of Didymodon (Pottiaceae) in Tibet, China. Plos one 2015; 10(7): e0132346. https:// doi.org/10.1371/journal.pone.0132346

23. Price TD, Qvarnström A, Irwin DE. The role of phenotypic plasticity in driving genetic evolution. The Royal Society 2003; 270: 1433-40. https://doi.org/10.1098/rspb.2003.2372 